\title{
PENGGUNAAN STRATEGI PENGORGANISASIAN PEMBELAJARAN DENGAN MODEL ELABORASI SEBAGAI UPAYA UNTUK MENINGKATKAN PRESTASI BELAJAR BIOLOGI SISWA DI KELAS X SMA NEGERI 7 KOTA BENGKULU
}

\author{
Salmeri Asrianengsi \\ SMA Negeri 7 Kota Bengkulu, Bengkulu \\ E-mail:salmeri1979@gmail.com (correspondence author)
}

\begin{abstract}
ABSTRAK
Penelitian ini bertujuan Untuk mengetahui penerapan strategi pengorganisasian pembelajaran model elaborasi dapat meningkatkan prestasi belajar biologi siswa kelas X SMA Negeri 7 Kota Bengkulu.. Penelitian ini merupakan penelitian tindakan kelas (PTK) yang dilaksanakan dalam 2 siklus, setiap siklus terdiri dari 4 tahap yaitu perencanaan, pelaksanaan, observasi, dan refleksi. Teknik pengumpulan data menggunakan tes bertujuan untuk mengetahui hasil belajar siswa sedangkan observasi melakukan pengamatan secara langsung ke objek penelitian untuk melihat dari dekat kegiatan yang dilakukan.. rata-rata aktivitas guru sebesar 33 yang termasuk dalam kategori baik dan skor rata-rata aktivitas siswa sebesar 28,5 yang termasuk ke dalam kategori cukup. Pada siklus II aktivitas guru mengalami peningkatan menjadi 37,5 yang termasuk dalam kategori baik dan skor ratarata aktivitas siswa sebesar 34,5 yang termasuk dalam kategori baik. Hasil tes pada siklus nilai ratarata dan ketuntasan belajar klasikal siswa mengalami peningkatan setiap siklus nilai rata-rata pada tes akhir siklus I sebesar 74,26 dan mengalami peningkatan pada hasil tes siklus II menjadi 89,43 sedangkan ketuntasan klasikal pada siklus I sebesar $80 \%$ meningkat menjadi $97,14 \%$ pada siklus II. Berdasarkan hasil penelitian, dapat disimpulkan bahwa Penggunaan Strategi Pengorganisasian Pembelajaran Dengan Model Elaborasi dapat meningkatkan aktivitas dan prestasi belajar biologi siswa kelas X SMA Negeri 7 Kota Bengkulu.
\end{abstract}

\section{Kata kunci: Aktivitas belajar, Prestasi Belajar dan Model Elaborasi}

\section{PENDAHULUAN}

Pendidikan adalah hal yang sangat penting dalam suatu bangsa. Dalam meningkatkan kualitas dan mutu sumber daya manusia, kita tidak bisa lari dari dunia pendidikan. Dalam UU sisdiknas no 20 tahun 2003 disebutkan "pendidikan adalah usaha sadar dan terencana untuk mewujudkan suasana belajar dan proses pembeljaran agar peserta didik secara aktif mengembangkan potensi dirinya untuk memiliki kekuatan spiritual keagamaan, pengendalian diri, kepribadian, akhlak mulia, serta keterampilan yang diperlukan dirinya, masyarakat, bangsa dan Negara". Jika kita kaitkan dengan pendidikan di sekolah, untuk meningkatkan kualitas sumber daya manusia tersebut, dapat dilakukan dengan cara memperbaiki sistem pengajaran.

Menurut Bukhori (2001) dalam trianto, pendidikan yang baik adalah pendidikan tidak hanya mempersiapkan para siswanya untuk sesuatu profesi atau jabatan, tetapi untuk menyelesaikan masalah-masalah dalam kehidupan sehari-hari yang dihadapinya.

Salah satu masalah pokok dalam pembelajaran pada pendidikan formal (sekolah) sejauh ini masih rendahnya daya serap pendidik. Hal ini nampak merata pada hasil belajar peserta didik yang senantiasa masih sangat memprihatinkan. Hasil belajar yang masih sangat rendah itu merupakan hasil kondisi pembelajaran yang masih bersifat konvensional dan tidak menyentuh ranah dimensi peserta didik itu sendiri, yaitu bagaimana sebenarnya pengertian belajar itu. Dalam arti yang lebih umum, bahwa proses pembelajaran hingga saat ini masih berpusat pada guru sehingga siswa menjdai pasif (Trianto. 2007).

Menurut Komarudin dalam Trianto, salah satu perubahan paradigma pembelajaran dalam pendidikan dan pembelajaran adalah orientasi pembelajaran yang awalnya berpusat pada guru dan beralih pada murid, metodologi yang 
semula lebih didominasi ekspositori berganti dengan partisipatori, dan pendekatan yang semula lebih banyak bersifat tekstual berubah menjadi kontekstual. Semua perubahan tersebut dimaksudkan untuk memperbaiki mutu pendidikan, baik dari segi proses maupun hasil pendidikan.

Salah satu hal lagi bahwa Kurikulum K13 (KTSP) sebagai hasil pembaharuan Kurikulum Tingkat Satuan Pendidikan (KTSP) juga menuntut suatu pembelajaran yang pada dasarnya tidak hanya mempelajari tentang konsep, teori dan fakta, tetapi juga aplikasi dalam kehidupan sehari-hari. Dengan demikian materi pembelajaran tidak hanya tersusun atas hal-hal sederhana yang bersifat hafalan dan pemahaman, tetapi juga tersusun atas materi kompleks yang memerlukan analisis, aplikasi dan sintesis. Untuk itu, guru harus bijaksana dalam menentukan suatu model yang sesuai dan dapat menciptakan situasi dan kondisi kelas yang kondusif agar proses belajar mengajar dapat berlangsung sesuai dengan tujuan yang diharapkan (Trianto. 2007).

Metode adalah cara yang digunakan untuk menyampaikan materi pelajaran dalam upaya mencapai tujuan kurikulum. Suatu metode mengandung pengertian terlaksananya kegiatan guru dan kegiatan siswa dalam proses pembelajaran. Metode dilaksanakan melalui prosedur tertentu. Metode mengajar merupakan suatu cara yang harus dilakukan dalam mengajar (Hamalik. 2008). Mengajar merupakan penyajian bahan pelajaran oleh guru kepada siswa dalam proses belajar agar dapat menerima, menguasai, dan mengembangkan bahan pelajaran. Di dalam proses belajar mengajar, guru harus bisa memilih metode mengajar agar siswa dapat belajar secara efektif dan efisien sehingga mengena pada tujuan yang diharapkan.

Berdasarkan observasi di kelas dengan guru bidang studi biologi di SMA Negeri 7 Kota Bengkulu, penulis memperoleh gambaran. Bahwa selama proses pembelajaran berlangsung hampir seluruh kegiatan pembelajaran masih berpusat pada guru. Metode dan model pembelajaran yang dipakai tidak beragam bentuknya, sehingga sebagian besar siswa susah memahami materi yang dijelaskan guru. Metode mengajar yang dilakukan selama ini pun mempengaruhi hasil belajar siswa. Sebagian siswa sulit untuk memahami materi yang dijelaskan oleh guru karena siswa kurang menguasai pengetahuan awal. Saat mengajar pada pertemuan pertama, guru tidak memberikan gambaran secara umum terhadap materi yang akan dibahas, sehingga siswa tidak tahu apa yang akan dipelajari pada pertemuan selanjutnya, siswa tidak memiliki gambaran materi inti yang harus dikuasai pada setiap pokok bahasan dan tidak dapat menghubungkan keterkaitan beberapa konsep-konsep yang ada. Guru juga mengatakan bahwa hasil ulangan harian untuk sub pokok bahasan Virus, sebagian besar siswa mendapatkan nilai dibawah 75, dimana Ketuntasan belajar yang ditetapkan sekolah untuk tingkat kelas dianggap tuntas apabila 85 $\%$ siswa di kelas memperoleh nilai 75 ke atas . Kondisi tersebut menunjukkan bahwa diperlukannya suatu usaha perbaikan dalam model pengajaran biologi yang dapat merangsang siswa untuk belajar secara aktif dalam proses belajar mengajar sehingga nantinya hasil belajar siswa dapat meningkat.

Berdasarkan hal tersebut maka peneliti ingin mengetahui apakah pengaruh Elaborasi dapat meningkatkan prestasi belajar siswa. Dengan model elaborasi ini, struktur isi pengajaran disampaikan langsung kepada siswa sehingga siswa memilki pedoman yang jelas dalam belajar. Siswa juga dilatih untuk aktif mandiri sehingga prestasi belajar siswa menjadi lebih baik.

\section{METODOLOGI PENELITIAN}

Penelitian dilakukan di SMA Negeri 7 Kota Bengkulu. Penelitian ini akan dilaksanakan pada bulan Maret tahun ajaran 2018/2019. Merupakan penelitian tindakan kelas (Classroom Action Research) terdiri dari empat tahap : 1) Perencanaan (planning), 2) pelaksanaan (acting), 3) Pengamatan (observasing), 4) Refleksi (reflecting), yang dilakukan dengan tujuan memeperbaiki mutu praktik pembelajaran di kelas (Arikunto, dkk. 2006).

Metode pengumpulan data yang digunakan dalam penelitian ini adalah dengan menggunakan tes dan observasi. 
Tes yang dilakukan pada peneliti ini terdiri dari tes akhir setiap siklus. Pretest untuk mengetahui tingkat pemahaman dan kesiapan siswa sebelum proses belajar mengajar. Tes akhir setiap siklus untuk memperoleh data hasil belajar siswa pada setiap siklus, dari data tersebut dapat dievaluasi apakah pada siklus tersebut mengalami peningkatan hasil belajar.

Sedangkan observasi yaitu melakukan pengamatan secara langsung ke objek penelitian untuk melihat dari dekat kegiatan yang dilakukan (Riduwan, 2006: 57). Observasi juga berfungsi sebagai alat penilaian. Observasi yang bernilai apabila dilaksanakan oleh guru dengan penuh minat, teliti, bersikap objektif, tepat dan lengkap (Hamalik. 2001)

Observasi atau pengamatan merupakan suatu teknik atau cara mengumpulkan data dengan jalan mengadakan pengamatan terhadap kegiatan yang sedang berlangsung (Sukmadinata. 2008).

Lembar observasi terdiri dari lembar observasi guru dan kegiatan siswa dalam pembelajaran.

Analisis data hasil tes dilakukan dengan menggunakan rumus sebagai berikut :

Nilai rata-rata siswa

$$
\bar{X}=\frac{\sum X}{n}
$$

(Riduwan. 2006)

Keterangan :

$$
\begin{aligned}
\bar{X} & =\text { Nilai rata-rata siswa } \\
\sum \mathrm{X} & =\text { Jumlah nilai siswa } \\
\mathrm{N} & =\text { Jumlah siswa }
\end{aligned}
$$

\section{Daya serap siswa}

$$
D S=\frac{\sum N S}{\sum S x N i} x 100 \%
$$

Keterangan :

$$
\begin{array}{ll}
\mathrm{DS} & =\text { Daya serap siswa } \\
\sum \mathrm{NS} & =\text { Jumlah nilai seluruh siswa } \\
\mathrm{Ni} & =\text { Nilai ideal }(100) \\
\sum \mathrm{S} & =\text { Jumlah siswa }
\end{array}
$$

\section{Ketuntasan Belajar}

Ketuntasan belajar klasikal $=\frac{\mathrm{NS}}{\mathrm{N}} \times 100 \%$

Keterangan :

$\mathrm{N}$ = jumlah seluruh siswa

$\mathrm{NS}=$ jumlah siswa yang mencapai 75 ke atas

(KKM SMA Negeri 7 Kota Bengkulu 2018/2019)

Analisa data observasi dilakukan dengan menghitung rata-rata skor pengamatan dengan rumus sebagai berikut :

Kisaran nilai untuk kriteria $=$

Skor tertinggi - skor terendah

Skor tertinggi setiap item

Dengan katagori kisaran sebagai berikut :

Tabel 1. Skor pengamatan setiap aspek yang diamati pada lembar observasi guru dan siswa

\begin{tabular}{|c|l|}
\hline \multicolumn{1}{|l|}{ Skor } & Kriteria \\
\hline 3 & Baik \\
\hline 2 & Cukup \\
\hline 1 & Kurang \\
\hline
\end{tabular}

Jumlah aspek yang diamati sebanyak 13 item, sehingga :

Skor tertinggi $=$ jumlah aspek yang diamati $\mathrm{x}$ skor tertinggi tiap item

Skor terendah $=$ jumlah aspek yang diamati $\mathrm{x}$ skorterendah tiap item

Skor tertinggi $=13 \times 3=39$

Skor terendah $=13 \times 1=13$

Kisaran nilai untuk kriteria = $\frac{39-13}{3}=\frac{26}{3}=8,66=9$

Tabel 2. Kisaran katagori analilis data observasi guru

\begin{tabular}{|l|l|}
\hline Kriteria & Katagori \\
\hline $31-39$ & Baik \\
\hline $22-30$ & Cukup \\
\hline $13-21$ & Kurang \\
\hline
\end{tabular}

\section{HASIL DAN PEMBAHASAN}

Berdasarkan hasil pengamatan yang dilakukan oleh pengamat 1 dan pengamat 2 terhadap guru yang melaksanakan proses pembelajaran biologi dengan menerapkan strategi pengorganisasian pembelajaran 
dengan model elaborasi pada konsep Bahan Kimia dalam Kehidupan pada siklus I dapat dilihat pada tabel 4.1 berikut :

Tabel 3. Skor Hasil Lembar Observasi Aktivitas Guru Pada Siklus I

\begin{tabular}{|l|l|l|}
\hline No. & Observer & Skor \\
\hline 1. & Observer 1 & 32 \\
2. & Observer 2 & 34 \\
\hline & Total & 66 \\
& Rata-rata & 33 \\
& Kriteria & Baik \\
\hline
\end{tabular}

Dari tabel 3 dapat diketahui bahwa secara umum aktivitas guru pada siklus 1 menurut observer 1 sebesar 32 dan menurut observer 2 sebesar 34. Jadi selama melaksanakan proses pembelajaran dengan menerapkan strategi pengorganisasian pembelajaran dengan model elaborasi berada pada kriteria baik dengan skor rata-rata 33 berarti guru sudah dikatakan aktif dalam melaksanakan proses pembelajaran.

Tetapi sesuai dengan hasil lembar observasi aktivitas guru dapat diketahui bahwa masih ada beberapa aspek yang belum terlaksana dengan baik yang hasilnya adalah :

Guru masih kurang menguatkan siswa terhadap materi prasyarat yang harus dikuasai siswa sebelum memasuki materi.

1. Guru kurang menjelaskan struktur pendukung yang harus dimiliki siswa.

2. Guru kurang memberikan kesempatan kepada siswa untuk bertanya.

3. Guru kurang mendorong siswa untuk menggunakan media pada saat pembelajaran berlangsung.

4. Guru kurang membahas hasil pekerjaan siswa, pada tahap kontrol siswa.

5. Guru kurang memberi tahu kepada siswa tentang materi yang akan dipelajari pada pertemuan selanjutnya.

Sedangkan hasil pengamatan yang dilakukan oleh pengamat 1 dan pengamat 2 terhadap siswa yang mengikuti proses pembelajaran biologi dengan menerapkan strategi pengorganisasian pembelajaran dengan model elaborasi pada siklus I dapat dilihat pada tabel 4.berikut :
Tabel 4. Skor Hasil Lembar Observasi Aktivitas Siswa Pada Siklus I

\begin{tabular}{|l|l|l|}
\hline No. & Observer & Skor \\
\hline 1. & Observer 1 & 28 \\
2. & Observer 2 & 29 \\
\hline & Total & 57 \\
& Rata-rata & 28,5 \\
& Kriteria & Cukup \\
\hline
\end{tabular}

Dari tabel 4.dapat diketahui bahwa secara umum aktivitas siswa pada siklus I menurut pengamat 1 diperoleh skor 28 dan pengamat 2 diperoleh 29. Jadi, selama melaksanakan proses pembelajaran dengan menerapkan strategi pengorganisasian pembelajaran dengan model elaborasi pada siklus 1 berada pada kriteria cukup dengan skor rata-rata 28,5 berarti siswa sudah dikatakan cukup dalam melaksanakan proses pembelajaran. Tetapi, sesuai dengan hasil lembar observasi aktivitas siswa dapat diketahui bahwa masih ada beberapa aspek yang belum terlaksana dengan baik yang hasilnya adalah :

1. Sebagian siswa tidak menguasai materi prasyarat belajar

2. Sebagian siswa tidak mendengarkan arahan mengenai tata tertib dan kelengkapan belajar

3. Sebagian siswa kurang bisa mengaikan materi yang diberikan guru.

4. Siswa belum bisa membuat ringkasan materi secara mandiri.

5. Ada beberapa siswa tidak memperhatikan secara serius penjelasan guru.

6. Ada sebagian siswa yang menyalin pada saat guru menjelaskan materi.

7. Siswa masih kurang termotivasi dalam belajar.

8. Pada saat diberikan kesempatan membaca dan memahami materi ada sebagian siswa yang tidak membaca.

9. Siswa kurang bisa menggunakan media.

10. Ada sebagian siswa yang tidak mengerjakan tugas, pada tahap kontrol siswa.

Setelah materi siklus I selesai maka diadakan tes akhir siklus I berupa tes pilihan ganda 10 soal dan tes esay sebanyak 2 soal yang kemudian dikerjakan secara individu. Tabel 5. Rekapan hasil tes pada siklus I 
Tabel 5. Rekapan hasil tes pada siklus I

\begin{tabular}{|l|l|l|l|l|l|}
\hline \multicolumn{5}{|c|}{ Hasil yang dicapai } & \multirow{2}{*}{ Ket } \\
\hline \multirow{2}{*}{$\begin{array}{l}\text { Nilai rata- } \\
\text { rata siswa }\end{array}$} & \multicolumn{3}{|l|}{ Keuntasan Individu } & Ketuntasan klasikal & \\
\cline { 2 - 5 } & Tuntas & Belum Tuntas & Ketercapaian & Standar & \\
\hline 74,26 & 28 & 7 & $80 \%$ & $85 \%$ & Belum tercapai \\
\hline
\end{tabular}

Berdasarkan tabel di atas terlihat bahwa 28 siswa yang telah tuntas belajar secara individu sedangkan 7 siswa lainnya belum tuntas secara individu, dan nilai rata-rata siswa adalah 74,26 dengan ketuntasan klasikal baru mencapai $80 \%$. Sementara standar ketuntasan klasikal menurut ketetapan sekolah yaitu mencapai $85 \%$.

Dengan demikian ketuntasan belajar secara klasikal pada siklus I belum tercapai.

Setelah pelaksanaan proses belajar mengajar pada penerapan model pembelajaran elaborasi, pada akhir siklus diadakan refleksirefleksi terhadap hasil-hasil yang telah diperoleh baik dari lembar observasi maupun hasil tes siklus, adapun aspek- aspek yang telah terlaksana dengan baik akan dipertahankan pada siklus II. Dan hal-hal yang belum tercapai pada siklus I perlu diperbaiki pada siklus II yaitu :

1. Perbaikan yang harus diperhatikan guru antara lain :

2. Guru harus menguatkan siswa terhadap materi prasyarat yang harus dikuasai siswa sebelum memasuki materi.

3. Guru harus menjelaskan struktur pendukung yang harus dimiliki siswa.

4. Guru harus memberikan kesempatan kepada siswa untuk bertanya.

5. Guru seharusnya mendorong siswa untuk dapat menggunakan media/ peralatan pada saat pembelajaran.

6. Guru hendaknya membahas hasil pekerjaan siswa dengan menyuruh salah satu siswa untuk menulis di papan tulis.

Perbaikan yang harus diperhatikan dalam aktivitas siswa yaitu :

1. Sebagian siswa tidak menguasai materi prasyarat belajar

2. Sebagian siswa tidak mendengarkan arahan mengenai tata tertib dan kelengkapan belajar

3. Sebagian siswa kurang bisa mengaikan materi yang diberikan guru.
4. Siswa belum bisa membuat ringkasan materi secara mandiri.

5. Ada beberapa siswa tidak memperhatikan secara serius penjelasan guru.

6. Ada sebagian siswa yang menyalin pada saat guru menjelaskan materi.

Ketuntasan belajar secara klasikal belum mencapai kriteria yang ditetapkan sekolah. oleh sebab itu, perlu dilaksanakan tindakan yang kedua (siklus II).

Siklus II dilaksanakan berdasarkan refleksi dari siklus I, artinya aspek-aspek yang sudah baik dipertahankan sedangkan aspek-aspek yang masih kurang dilakukan perbaikan pada siklus II ini.

Seperti pada siklus I, observasi dilakukan oleh dua orang observer untuk mencatat semua perubahan yang terjadi pada siswa dan guru dengan cara mengamati keseluruhan proses pembelajaran sesuai dengan aspek pengamatan yang telah di siapkan.

Berdasarkan hasil pengamatan yang telah dilakukan oleh pengamat 1 dan pengamat 2 terhadap guru yang melaksanakan proses pembelajaran biologi dengan menerapkan strategi pengorganisasian pembelajaran dengan model elaborasi pada siklus II dapat dilihat pada tabel 4.4 berikut :

Tabel 6. Skor Hasil Lembar Observasi Aktivitas Guru Pada Siklus II

\begin{tabular}{|l|l|l|}
\hline No. & Observer & Skor \\
\hline 1. & Observer 1 & 37 \\
2. & Observer 2 & 38 \\
\hline & Total & 75 \\
& Rata-rata & 37,5 \\
& Kriteria & Baik \\
\hline
\end{tabular}

Dari tabel 6. dapat diketahui bahwa secara umum aktivitas guru pada siklus I menurut observer 1 sebesar 37 dan menurut observer 2 sebesar 38. Jadi selama melaksanakan proses pembelajaran dengan menerapkan strategi pengorganisasian pembelajaran dengan model elaborasi berada pada kriteria baik dengan 
skor rata-rata 37,5 berarti guru sudah dikatakan aktif dalam melaksanakan proses pembelajaran. Tetapi, sesuai dengan hasil lembar observasi aktivitas guru dapat diketahui bahwa.

1. Guru masih kurang menguatkan siswa terhadap materi prasyarat yang harus dikuasai siswa sebelum memasuki materi.

2. Guru masih kurang menjelaskan struktur pendukung yang harus dimiliki siswa.

3. Guru masih kurang member tahu tentang materi pertemuan selanjutnya.

Berdasarkan hasil pengamatan yang dilakukan oleh observer 1 dan observer 2 terhadap siswa yang mengikuti proses pembelajaran biologi dengan menerapkan strategi pengorganisasian pembelajaran dengan model elaborasi pada siklus II dapat dilihat pada tabel 4.5 berikut :

Tabel 7. Skor Hasil Lembar Observasi Aktivitas Siswa Pada Siklus II

\begin{tabular}{|l|l|l|}
\hline No. & Observer & Skor \\
\hline 1. & Observer 1 & 35 \\
2. & Observer 2 & 34 \\
\hline & Total & 69 \\
& Rata-rata & 34,5 \\
& Kriteria & Baik \\
\hline
\end{tabular}

Dari tabel 7 dapat diketahui bahwa secara umum aktivitas siswa pada siklus II menurut observer 1 diperoleh skor 35 dan observer 2 diperoleh 34. Jadi, selama melaksanakan proses pembelajaran dengan menerapkan strategi pengorganisasian pembelajaran dengan model elaborasi pada siklus II berada pada kriteria baik dengan skor rata-rata 34,5 berarti siswa sudah dikatakan baik dalam melaksanakan proses pembelajaran. Tetapi, Tabel 8. Rekapan hasil tes pada siklus II

\begin{tabular}{|l|l|l|l|l|l|}
\hline \multicolumn{5}{|c|}{ Hasil yang dicapai } & \multirow{2}{*}{ Ket } \\
\hline \multirow{2}{*}{$\begin{array}{l}\text { Nilai rata- } \\
\text { rata siswa }\end{array}$} & \multicolumn{2}{|c|}{ Keuntasan Individu } & Ketuntasan klasikal & \\
\cline { 2 - 5 } & Tuntas & BelumTuntas & Ketercapaian & Standar & \\
\hline 89,43 & 34 & 1 & $97,14 \%$ & $85 \%$ & Sudah tercapai \\
\hline
\end{tabular}

Berdasarkan tabel di atas terlihat bahwa 34 siswa telah tuntas belajar secara individu dan hanya 1 siswa saja yang belum tuntas secara individu, dan nilai rata-rata siswa adalah 89,43 dengan ketuntasan klasikal mencapai 97,14\%. telah mencapai standar ketuntasan klasikal sesuai dengan hasil lembar observasi aktivitas siswa dapat diketahui bahwa :

1. Sebagian siswa kurang mengetahui struktur isi materi pembelajaran.

2. Sebagian siswa masih belum mengetahui materi prasyarat yang harus siswa ketahui.

3. Pada siklus II ini motivasi belajar mengajar belum kondusif siswa kelas lain yang tidak belajar berkeliaran di sekitar kelas mengganggu kosentrasi belajar siswa.

4. Beberapa siswa masih tidak komitmen dengan kesepakatan yang dibuat untuk membawa perlengkapan belajar, siswa tersebut meminjam dengan teman yang lain sehingga menghambat kerja teman yang lain.

5. Masih ada juga beberapa siswa sesekali terlihat mengobrol dan keluar pada saat disuruh membaca dan memahami materi.

6. Pada tahap kontrol siswa, masih ada beberapa siswa yang tidak mengerjakan tugas mencari soal beserta penyelesaiannya.

Setelah materi siklus II selesai maka diadakan tes akhir siklus II berupa tes pilihan ganda 10 soal dan tes esay sebanyak 2 soal yang kemudian dikerjakan secara individu.

Berdasarkan hasil post tes siklus II, menunjukkan bahwa diperoleh peningkatan hasil belajar siswa dibandingkan dengan tes akhir siklus I. jika pada akhir tes siklus I nilai rata-rata 74,26 maka pada siklus II nilai ratarata siswa adalah 89,45 . hasil nilai akhir siklus dapat dilihat pada tabel 8 . di bawah ini : 
Berdasarkan hasil pengamatan aktivitas guru dan siswa serta hasil evaluasi selama proses pembelajaran sudah mampu menampilkan hasil yang optimal.hal ini dapat dilihat dari semua aspek dan pengamatan aktivitas guru dan siswa, dan tes akhir yang mengalami peningkatan. Guru sudah mampu memusatkan perhatian siswa terhadap pembelajaran biologi serta mampu memancing siswa untuk menjawab pertanyaan yang guru berikan sehingga terlihat siswa aktif dalam pembelajaran.

Hasil belajar menunjuk pada prestasi belajar, sedangkan prestasi belajar itu merupakan indikator adanya derajat perubahan tingkah laku siswa (Hamalik, 2008). Bukti bahwa seseorang telah belajar ialah terjadinya perubahan tingkah laku pada orang tersebut, misalnya dari tidak tahu menjadi tahu, dan dari tidak mengerti menjadi mengerti. Hasil belajar akan tampak pada setiap perubahan (Hamalik, 2008).

\section{Hasil Belajar Siswa}

Terbukti pada penelitian ini bahwa strategi pengorganisasian dengan model elaborasi ini meningkatkan prestasi belajar siswa yang ditunjukkan berdasarkan nilai tes yang sudah dianalisis, diketahui bahwa terjadi peningkatan hasil belajar siswa dimana skor rata-rata yaitu 74,26 pada siklus I meningkat menjadi 89,43 pada siklus II. Ketuntasan belajar sebesar $80 \% \%$ pada siklus I meningkat menjadi 97,14\% pada siklus II. Pada siklus II hasil belajar siswa lebih baik dari siklus sebelumnya. Hal ini menunjukkan bahwa hasil belajar siswa kelas X SMA Negrei 7 Kota Bengkulu. mengalami Peningkatan setiap siklus tersebut disebabkan oleh beberapa faktor, diantaranya :

Guru telah berusaha maksimal untuk menerapkan strategi pengorganisasian pembelajaran dengan model elaborasi yang membantu guru menyampaikan materi pelajaran

Siswa telah menyimak dengan baik apa yang telah disampaikan oleh guru

Pada siklus I dan II siswa juga telah di bimbing dalam membuat sintesis dan ringkasan materi yang belum mereka pahami.

\section{Aktivitas Belajar Siswa}

Model elaborasi merupakan proses penambahan rincian, sehingga informasi baru akan lebih bermakna. Elaborasi akan membantu pemindahan informasi baru dari memori jangka pendek ke memori jangka panjang dengan menciptakan gabungan dan hubungan antara informasi baru dan apa yang telah diketahui (Aqib dan Rohmanto, 2008).

Strategi pengorganisasian adalah "metode untuk mengorganisasikan isi bidang studi yang telah dipilih untuk pengajaran. Mengorganisasikan mengacu pada suatu tindakan seperti pemilihan isi, penataan isi, pembuatan diagram, format dan lainnya yang setingkat dengan itu" (Uno, 2007).

Berdasarkan data hasil penelitian pada proses pembelajaran melalui penerapan strategi pengorganisasian model elaborasi dari dua siklus yang telah dilaksanakan terdapat peningkatan aktivitas belajar siswa yaitu pada siklus I keaktifan siswa masih dalam kategori cukup dengan nilai rata-rata pengamatan terhadap siswa sebesar 28,5. dari lembar observasi tersebut diketahui bahwa guru masih kurang menguatkan siswa terhadap materi prasyarat yang harus dikuasai siswa sebelum memasuki materi dan guru kurang menjelaskan struktur pendukung yang harus dimiliki siswa.

Sementara ada sebagian siswa kurang mengetahui tujuan pembelajaran, sebagian siswa tidak menguasai materi prasyarat belajar, sebagian siswa masih kurang memperhatikan penjelasan guru, dan sebagian siswa kurang bisa membuat ringkasan materi pelajaran sendiri.

Selanjutnya Berdasarkan hasil lembar observasi pada siklus II diketahui bahwa keaktifan siswa selama pembelajaran biologi dengan menerapkan strategi pengorganisasian dengan model elaborasi berada dalam kategori baik dan aktif. Hal ini ditunjukkan dari skor rata-rata pengamatan terhadap siswa-siswa sebesar 34,5. dari hasil observasi tersebut dapat diketahui bahwa siswa telah memperhatikan penjelasan guru dan siswa telah termotivasi dalam belajar, Peningkatan ini terjadi karena pada model pembelajaran elaborasi siswa dituntut untuk lebih aktif. 
Adapun upaya yang dilakukan guru untuk meningkatkan aktivitas siswa selama pembelajaran sebagai berikut :

1. Guru menguatkan siswa terhadap materi prasyarat yang harus dikuasai siswa sebelum memasuki materi.

2. Guru lebih mengutamakan pemberian reward seperti perlengkapan belajar, dukungan dan motivasi

3. Guru memberikan lebih banyak kesempatan kepada siswa untuk bertanya tentang materi yang telah dipelajari
4. Guru berusaha mengaitkan dan menganalogikan materi dengan melibatkan siswa secara langsung

5. Guru lebih membimbing siswa yang memiliki kemampuan rendah dibandingkan dengan siswa yang berkemampuan tinggi pada saat sebagian mengerjakan latihan soal dengan cara mendekati siswa tersebut secara langsung

6. Guru lebih membimbing siswa meringkas materi.

Berikut ini perkembangan peningkatan prestasi dan aktifitas siswa setiap siklus yang disajikan dalam tabel 9. berikut ini :

Tabel 9. Hasil Peningkatan Prestasi dan Aktifitas Siswa Setiap Siklus

\begin{tabular}{|l|l|l|l|l|l|l|}
\hline \multirow{2}{*}{ No } & \multirow{2}{*}{ Siklus } & \multicolumn{2}{|l|}{ Skor Observasi } & \multirow{2}{*}{$\begin{array}{l}\text { Ketuntasan } \\
\text { Individu }\end{array}$} & $\begin{array}{l}\text { Presentase } \\
\text { Ketuntasan }\end{array}$ & kriteria \\
\cline { 3 - 4 } & Siswa & Kriteria & & $80 \%$ & Belum tercapai \\
\hline 1 & I & 28,5 & Cukup & 28 & $97,14 \%$ & Tercapai \\
\hline 2 & II & 34,5 & Baik & 34 & & $90 \%$ \\
\hline
\end{tabular}

Dari tabel diatas terlihat peningkatan prestasi dan aktivitas siswa meningkat setiap siklusnya.

\section{KESIMPULAN}

Berdasarkan hasil penelitian yang telah dilaksanakan dengan Penggunaan Strategi Pengorganisasian Pembelajaran Dengan Model Elaborasi dapat meningkatkan aktivitas dan prestasi belajar biologi siswa kelas $\mathrm{X}$ SMA Negeri 7 Kota Bengkulu.

\section{DAFTAR PUSTAKA}

Aqib, Zainal dan Rohmanto, Elham. 2008. Membangun Profesionalisme Guru dan Pengawas Sekolah. Badung: Yrama Widya.

Arikunto, dkk. 2006. Penelitian Tindakan Kelas. Jakarta: Bumi Aksara.

Arikunto, Suharsimi. 2002. Prosedur Penelitian Suatu Pendekatan Praktek (edisi revisi). Jakarta: Rineka Cipta.

Hamalik, Oemar. 2001. Proses Belajar Mengajar. Jakarta : Bumi Aksara.

Hamalik, Oemar. 2008. Kurikulum dan Pembelajaran. 2008. Jakarta: Bumi Aksara.
Riduwan. 2006. Dasar-dasar Statistika. Bandung: Alfabeta.

Sardiman. 2004. Interaksi dan Motivasi Belajar Mengajar. Jakarta: Raja Grafindo Persada.

Sukamadinata, Nana Syaodih. 2008. Metodologi Penelitian Pendidikan. Bandung: Remaja Rosdakarya.

Trianto. 2007. Model-Model Pembelajaran Inovatif Berorientasi Konstruktinistik. Jakarta: Pretasi Pustaka Publisher.

Uno, Hamzah. 2007. Model Pembelajaran. Jakarta: Bumi Aksara.

Uno, Hamzah. 2007. Perencanaan Pembelajaran. Jakarta: Bumi Aksara. 